\title{
Transition to Distance Education in COVID-19 Period: Turkish Pre-Service Teachers' E-Learning Attitudes and Readiness Levels
}

Tarık Balcı (Corresponding author)

Department of Physical Education and Sports Teaching, Faculty of Sport Sciences

Balıkesir University, Balıkesir, Turkey

E-mail: baun.tarikbalci@gmail.com

\section{Ceren Nur Temiz}

Department of Physical Education and Sports, Health Sciences Institute

Balıkesir University, Balıkesir, Turkey

E-mail: cerennur.temiz@baun.edu.tr

\author{
Ahmet Haktan Sivrikaya \\ Department of Physical Education and Sports Teaching, Faculty of Sport Sciences \\ Balıkesir University, Balıkesir, Turkey \\ E-mail: sivrikaya@balikesir.edu.tr
}

Received: April 7, 2021 Accepted: May 5, $2021 \quad$ Published: May 14, 2021

doi:10.5296/jei.v7i1.18508 URL: https://doi.org/10.5296/jei.v7i1.18508

\begin{abstract}
In this study, pre-service teachers' attitudes and readiness towards e-learning during the COVID-19 pandemic were examined. This research was carried out in the Fall Semester of the 2020-2021 Academic Year, with the participation of 519 pre-service teachers from Balıkesir University Necatibey Faculty of Education and Faculty of Sport Sciences, Department of Physical Education and Sports Education. In the collection of data, the General Attitude Scale towards e-learning developed by Haznedar and Baran (2012) and the Online Learning Readiness Scale adapted to Turkish Culture by İlhan and Çetin (2013), were
\end{abstract}


used. In this study, it was found that pre-service teachers had a negative attitude towards e-learning and that they considered themselves competent in terms of e-learning readiness. There was no difference in terms of e-learning attitudes and readiness of the teacher candidates according to the department they studied. In addition, it was found that there was a significant relationship between pre-service teachers' attitudes towards e-learning and their readiness, and that e-learning readiness was an effective factor in the adoption of the e-learning process.

Keywords: COVID-19, E-learning, E-learning attitudes, E-learning readiness, Pre-service teachers

\section{Introduction}

COVID-19, which emerged in Wuhan region of China towards the end of 2019, quickly spread and had an effect all over the world. Following the announcement of World Health Organization that the fast-spreading COVID-19 virus was a pandemic, one of the sectors that were mainly hit was education as well as the health and economy sectors. As a result of this, higher education institutions were obliged to launch distance education activities on an unprecedented scale. According to Radha, Mahalakshmi, Kumar, and Saravanakumar (2020), this worldwide pandemic forced educational institutions to close down so that virus spread could be kept under control and to focus on seeking alternative methods in education. Thus, educational activities were based on digital platforms such as web-based learning, e-learning or online learning.

Since it was not known when the pandemic would disappear completely, educational institutions worldwide decided to use the already available technical sources in order to establish online learning materials (Kaur, 2020). Although it was an appropriate action in terms of crisis management and public health that universities discontinued face to face learning suddenly and immediately and launched courses in online media, shortly afterward this caused the students to find this hasty distance education insufficient and unsuccessful (Erkut, 2020). Those institutions that had no experience or a limited experience with e-learning and did not prepare e-learning sources, and had instructors who had difficulties about how to use online sources encountered problems (Zaharah, Kirilova, \& Windarti, 2020).

Distance education, removing time and place restrictions, has become an educational application used widely today (A ğır, Gür, \& Okçu, 2007); it has also been changed into the most popular educational method used as an essential tool of education and learning in the period of the "new normal". Distance education has eliminated the necessity that time and place have to be the same for all learners and has turned into virtual classes that are flexible and independent and vary depending on the learners' autonomy. These virtual classrooms, where learnings are provided by way of the Internet, have led to the emergence of some terms. One of these terms, electronic learning (e-learning), is a general term used to define a learning mode in which instructor and learner are separated from each other in place or time, and the gap between them is closed with the use of online technologies (Egbo, Okoyeuzu, Ifeanacho, \& Onwumere, 2011). It is an arrangement where learning is acquired through 
technology and the Internet (Gros \& García-Peñalvo, 2016; Hong, Tai, Hwang, Kuo, \& Chen, 2017; Aljawarneh, 2020); where individuals receive or upload a certain online content from the Internet being independent of time and place (Zhang \& Nunamaker, 2003); and where intraclass and extra class teaching and learning is realized through information and communication technologies (Frehywot et al., 2013). In the literature; it is evident that terms such as e-learning, online learning, Internet-based learning, web-based learning, computer-based learning, synchronized and asynchronized learning and blended learning are often used interchangeably (Smart \& Cappel, 2006; Çakır \& Horzum, 2015; Dhawan, 2020). Although these terms are subtly different, they, in general, reflect the same idea (Kamarulzaman, Madun, \& Ghani, 2011). In the current study; e-learning was used as a general term.

\subsection{E-Learning Attitudes}

In e-learning, one of the factors that influences productivity and student success is their attitudes towards e-learning. According to Schwartz (2012), attitudes are views about objects as "good or bad" or "desired or undesired". It is stated by Üstüner (2006) that knowing one's attitude towards an object or stimulus will provide a prediction as to how one will act for the object and stimulus in question. Students with a positive attitude towards e-learning are expected to be more ready to learn; which will, more likely, help them produce more learning outputs of higher quality and therefore, a higher level of academic achievements (Hergüner, S. B. Son, S. H. Son, \& Dönmez, 2020). Meanwhile, it is argued that exploring students' attitudes towards e-learning may suggest an idea about to what extent they will use an e-learning system (Ong \& Lai, 2006).

The researches carried out showed predictably that positive attitudes towards e-learning have positively affected active participation in e-learning activities (Aixia \& Wang, 2011; Zhu, 2012; Rhema \& Miliszewska, 2014). On the other hand; it is possible that negative emotions and views about online courses could lead to a negative effect upon students' academic stability and success (Zembylas, 2008; DeVaney, 2010; Tempelaar, Niculescu, Rienties, Gijselaers, \& Giesbers, 2012). The results of the study carried out by Alawamleh, Al-Twait, and Al-Saht (2020) with university students during COVID-19 pandemic identified that many problems -such as students' lack of motivation in online courses, low level of communication between instructors and students, and feeling of isolation - had negative effects upon students and therefore, students chose face to face courses in classrooms instead of online courses. Radha et al. (2020) conducted a study with the participation of the students from different universities and schools during COVID-19 pandemic, and reported that students favored e-learning in general and were eager for e-learning; and that e-learning improved individual study skills and therefore was useful; however, most of the students were of the opinion that face-to-face learning (classroom environments) was more effective for both learning applied skills and general learning environment preference.

\subsection{E-Learning Readiness}

Students' e-learning readiness is accepted as a significant indicator that e-learning courses can successfully be performed and completed (Demir, 2015). For e-learning programs to be 
successful, it is essential that students' readiness be examined and necessary infrastructures and materials are provided (Ergün \& Kurnaz Adıbatmaz, 2020). Additionally; determining levels of students' readiness for e-learning will make contributions to designing efficient online courses. Thus, students will attend more successful and productive online learning experiences (Hung, Chou, Chen, \& Own, 2010).

E-learning readiness is defined as being mentally and physically ready for e-learning experiences and activities (Borotis \& Poulymenakou, 2004); as the extent to which as to how much individuals are willing and ready to benefit from information and communication technologies (Dada, 2006); and as an ability to use multimedia technologies and learning sources so that learning quality can be enhanced (Kaymak-Demir \& Horzum, 2013). Warner, Christie, and Choy (1998) defined e-learning readiness in three aspects: i) students' preferences for the form of delivery instead of face-to-face classroom instruction; ii) student confidence in using electronic communication for learning and, particularly, competence and confidence in the use of the Internet and computer-mediated communication; and iii) ability to undertake autonomous learning. On the other hand; Hung et al. (2010) argued that people's e-learning readiness has consisted of five factors: computer/Internet self-efficacy, online communication self-efficacy, self-directed learning, learner-control and motivation for learning.

It is pointed out that, even if institutions that initiate distance education activities are equipped with sufficient infrastructure, they should absolutely take students' and instructors' readiness status into consideration (Sakal, 2017), and e-learning readiness is one of the most crucial factors in obtaining successful results from e-learning programs (Oliver, 2001; So \& Swatman, 2006; Artino, 2009; Galy, Downey, \& Johnson, 2011; Kruger-Ross \& Waters, 2013). It will doubtlessly affect the learning process positively for students to feel ready for every aspect of the learning process. Hence, students' readiness level is highly important in the learning process (Aş1lığlu, Murat, \& Demir, 2018) and is accepted as one of the factors that directly make students continue or discontinue in the learning process (Demir Kaymak \& Horzum, 2013).

According to the research results of Horzum, Demir Kaymak, and Güngören (2015), it was concluded that as students' readiness levels for online learning increase, so do their academic motivations and perceived learning levels; and accordingly, readiness is concluded to be a key predictor of academic motivation. In another study; Y1lmaz (2017) reported that students' readiness for e-learning is a significant predictor of course satisfaction and motivation in flipped classroom teaching model. The study by Topal (2016) showed that students' readiness for e-learning levels affected their satisfaction positively. In this study; those students with higher ability for learning control, motivation for learning, and self-directed learning demonstrated a higher level of e-learning satisfaction. In addition, other studies reported that there is a positive correlation between students' attitudes towards e-learning and their readiness levels (Jena, 2016; Obi et al., 2018; Hergüner et al., 2020).

The present study was conducted in a period in which teaching method was decided to be distance education due to COVID-19 Pandemic. When recent studies were examined, it was 
seen that the number of studies that investigated students' and teacher candidates' attitudes towards e-learning and their readiness during the pandemic, was rather limited. Therefore; we are of the opinion that the results to be obtained from this study will be significant and thus contribute usefully to the literature. This study focused on determining the attitudes towards e-learning and the readiness levels of pre-service teachers who took courses through the distance education method at Balıkesir University during COVID-19 Pandemic period.

\section{Method}

\subsection{Research Design}

This study, which examined attitudes towards e-learning and readiness levels of pre-service teachers during COVID-19 Pandemic period, was conducted in a survey model. Survey models are the research approach in which the whole population or a sample, a group or a set of the population is surveyed in order to arrive at a general conclusion about the same population composed of its many components. The case, individual or object that is the subject of the research is described as far as possible within its own conditions and without making any effort to change and affect it (Karasar, 2017).

\subsection{Participants}

A total of 519 pre-service teachers who attended Necatibey Education Faculty and Sports Sciences Faculty- Physical Education and Sports Department of Balıkesir University joined the study during the fall semester of 2020-2021 academic year. Pre-service teachers at the university took distance education activity in an orderly manner through Microsoft Teams during the fall semester of 2020-2021 academic year for the first time. Because of the pandemic, the research data were collected over www.onlineanketler.com between the $16^{\text {th }}$ and the $29^{\text {th }}$ of November 2020. Information about the participants Is presented in Table 1. 
Table 1. Participants

\begin{tabular}{|l|l|l|l|}
\hline Variable & Group & $\mathrm{f}$ & $\%$ \\
\hline \multirow{4}{*}{ Gender } & Female & 379 & 73.0 \\
\cline { 2 - 4 } & Male & 140 & 27.0 \\
\hline \multirow{5}{*}{ Department } & Social Sciences and Turkish Language & 206 & 39.7 \\
\cline { 2 - 4 } & Mathematics and Science & 163 & 31.4 \\
\cline { 2 - 4 } & English Language & 46 & 8.9 \\
\cline { 2 - 4 } & Physical Education and Sports & 104 & 20.0 \\
\hline \multirow{5}{*}{ Grade } & $18-20$ & 252 & 48.6 \\
\cline { 2 - 5 } & $21-23$ & 208 & 40.1 \\
\cline { 2 - 5 } & $\geq 24$ & 59 & 11.4 \\
\hline \multirow{5}{*}{ Total } & First Grade & 138 & 26.6 \\
\cline { 2 - 5 } & Second Grade & 94 & 18.1 \\
\cline { 2 - 4 } & Third Grade & 98 & 18.9 \\
\cline { 2 - 4 } & Fourth Grade & 189 & 36.4 \\
\hline
\end{tabular}

According to the results shown in Table 1; it was identified that $73 \%$ of the participants were female and $27 \%$ of them were male, 39.7 of them were pre-service teachers at the Department of Social Sciences and Turkish Language Teaching, 31.4\% of them at the Department of Mathematics and Science Teaching, 8.9\% of them at the Department of English Language Education and 20\% of them at Physical Education and Sports Department. $48.6 \%$ of the candidate teachers were aged between $18-20$ years, $40.1 \%$ of them were aged between $21-23$ years and $11.4 \%$ of them were aged $\geq 24$ years. When academic grades of the participant pre-service teachers were examined, they showed that $26.6 \%$ of the students were studying to the first grade, $18.1 \%$ to the second grade, $18.9 \%$ to the third grade and $36.4 \%$ to the fourth grade.

\subsection{Data Collection Tools}

\subsubsection{A General Attitude Scale Towards E-learning}

General Attitude Scale Towards E-learning (GASTEL), used in the study, was developed by Haznedar and Baran (2012) to determine the e-learning attitudes of the university students who studied at the Faculty of Education. GASTEL is a five-point Likert scale with a total of 20 items. It has consisted of two subdimensions: "tendency towards e-learning (TTEL)" and "avoidance from e-learning (AFEL)". This two-factor structure explained $52.23 \%$ of the 
variance of e-learning attitude (ELA). It was identified that item factor loading varied between 0.63 and 0.80 for a tendency towards e-learning and it varied between 0.51 and 0.65 for avoidance from e-learning. In the scale development research (Haznedar \& Baran, 2012), The Cronbach's alpha internal consistency coefficients showed that the scale was a reliable scale and the coefficients were found to be 0.93 for "the tendency towards e-learning" and 0.84 for "the avoidance from e-learning" and 0.93 for the total scale. Higher scores obtained from "the tendency towards e-learning" subscale and from the total scale as one factor indicate that participants have a positive attitude whereas higher scores obtained from "the avoidance from e-learning" subscale indicate that participants have a negative attitude.

In this study, first-order confirmatory factor analysis was done in order to test two factor structure of the scale. Fit indices obtained as a result of the factor analysis $\left(\mathrm{x}^{2} / \mathrm{df}=3.35\right.$, $\mathrm{RMSEA}=0.06, \mathrm{GFI}=0.89, \mathrm{CFI}=0.94, \mathrm{IFI}=0.94, \mathrm{NFI}=0.92, \mathrm{RMR}=0.05$ ) demonstrated that the model was confirmed and was valid to measure the general attitudes towards e-learning. In the current study; reliability coefficients of GASTEL were calculated to be 0.93 for "the tendency towards e-learning" subscale, 0.90 for "the avoidance from e-learning" subscale and 0.95 for total scale.

\subsubsection{Online Learning Readiness Scale}

The Online Learning Readiness Scale (OLRS), another scale used in this study, was developed by Hung et al. (2010), and its adaptation into Turkish Culture was performed by İlhan and Çetin (2013). OLRS is a five-point Likert scale with a total of 18 items. The scale consists of five subscales: "computer/Internet self-efficacy (CIS)", "self-directed learning (SDL)", "learner control (LC)", "motivation for learning (MFL)" and "online communication self-efficacy (OCS)". Item factor loadings varied between 0.82 and 0.85 for CIS, between 0.63 and 0.90 for SDL, between 0.52 and 0.84 for LC, between 0.78 and 0.85 for MFL and between 0.76 and 0.82 for OCS. In the adaptation study of OLRS for Turkish Culture; the goodness of fit indices of this five-factor model confirmed the model and indicated that it was a valid model for measuring online learning readiness $\left(\mathrm{x}^{2} / \mathrm{df}=2.69, \mathrm{RMSEA}=0.89, \mathrm{CFI}=\right.$ $0.98, \mathrm{NFI}=0.96, \mathrm{NNFI}=0.97, \mathrm{RFI}=0.95, \mathrm{IFI}=0.98, \mathrm{SRMR}=0.058, \mathrm{PNFI}=0.79, \mathrm{PGFI}=$ 0.62 ). In the adaptation studies of the scale; internal consistency, split-half test, test-retest and composite reliability methods were used in order to explore the reliability of OLRS. The Cronbach's alpha internal consistency coefficients ranged from 0.76 to 0.95 for subscales and total scale. The higher scores obtained from the subscales and total scale indicated a higher level of online learning readiness.

In this study; first-order a confirmatory factor analysis was carried out in order to test the five-factor structure of the scale. Fit indices obtained as a result of the factor analysis $\left(\mathrm{x}^{2} / \mathrm{df}=\right.$ 3.61, RMSEA $=0.07$, GFI $=0.91$, CFI $=0.92$, IFI $=0.92$, NFI $=0.89$, RMR $=0.03$ ) demonstrated that the model was confirmed and was valid to measure online learning readiness. In the current study; reliability coefficients of OLRS were calculated to be 0.84 for "CIS" subscale, 0.80 for "SDL" subscale, 0.65 for "LC" subscale, 0.72 for "MFL" subscale, " 0.78 " for "OCS" subscale and 0.91 for total scale. 


\subsection{Statistics and Data Analysis}

After ethical and scientific approval to undertake this study was gained from the Ethics Committee of Social Sciences and Humanities of Balıkesir University (Date: 12/11/2020; Number: 19928322-100), and necessary official permissions having been obtained from the academic faculties and instructors; study data were collected through https://www.onlineanketler.com/ because of the COVID-19 Pandemic; and the data obtained were processed with the SPSS 26 (Statistical Package for the Social Sciences) package program. Four survey forms that were incompletely filled in during coding, and the measurement data of three pre-service teachers who attended to two academic departments were taken out of data set due to the very limited response, before analyzing the study data. Later, the suitability of the data set for parametric statistical analysis was studied. Later; $\mathrm{z}$ score $( \pm 3.29)$ and coefficients of skewness and kurtosis $( \pm 2)$ (George \& Mallery, 2010) were analyzed and 6 data sets that were far from normal distribution were excluded from the data set. To analyze the data; descriptive statistical methods (percentages, frequency, means and standard deviation), as well as independent sample t test (in order to explore whether there was any difference in candidate teachers' views in terms of gender) and one-way analysis of variance (ANOVA) (in order to explore whether there was any difference in candidate teachers' views in terms of academic departments and age), were employed. Also, the Scheffe Test that did not require equality of group numbers was performed in order to explore among which groups differences existed as a result of variance analyses (Lorcu, 2015). For examination of the relationship between e-learning attitude and e-learning readiness, Pearson correlation analysis was used. The correlation coefficients were evaluated as highly correlated between $0.70-1.00$, moderately correlated between $0.70-0.30$, and weakly correlated between 0.30-0.00 (Büyüköztürk, 2018). To predict e-learning attitudes; simple linear regression analysis was employed. In all analyses, $\mathrm{p}<0.05$ was determined as the level of significance.

\section{Results}

When the findings in Table 2 were examined; it was seen that pre-service teachers' tendency towards e-learning scores were at a low level $(\mathrm{M}=2.59 \pm 0.88)$, and their avoidance from e-learning scores was above the average $(\mathrm{M}=3.40 \pm 0.88)$. When candidate teachers' attitudes towards e-learning were viewed in a general sense; it was understood that candidate teachers were closer to negative attitudes towards e-learning $(\mathrm{M}=2.60 \pm 0.85)$. When the findings in Table 2 were examined in terms of e-learning readiness; pre-service teachers' readiness levels were, in general, above the average $(\mathrm{M}=3.73 \pm 0.56)$. The participants considered themselves self-sufficient in motivation for learning $(\mathrm{M}=4.04 \pm 0.60)$ at the highest level, while in learning control $(\mathrm{M}=3.47 \pm 0.70)$ and computer/Internet self-efficacy $(\mathrm{M}=3.57 \pm 0.88)$ at the lowest level. 


\section{Ml Macrothink}

Table 2. Descriptive statistics related with pre-service teachers' attitudes and readiness towards e-learning

\begin{tabular}{|l|l|l|l|l|l|}
\hline & $\mathrm{M}$ & $\mathrm{SD}$ & Skewness & Kurtosis & $\alpha$ \\
\hline TTEL & 2.59 & 0.88 & 0.487 & -0.006 & 0.93 \\
\hline AFEL & 3.40 & 0.88 & -0.488 & -0.059 & 0.90 \\
\hline ELA & 2.60 & 0.85 & 0.511 & 0.054 & 0.95 \\
\hline CIS & 3.57 & 0.88 & -0.457 & 0.229 & 0.84 \\
\hline SDL & 3.70 & 0.66 & -0.295 & 0.251 & 0.80 \\
\hline LC & 3.47 & 0.70 & -0.148 & 0.508 & 0.65 \\
\hline MFL & 4.04 & 0.60 & -0.464 & 0.459 & 0.72 \\
\hline OCS & 3.80 & 0.80 & -0.733 & 0.875 & 0.78 \\
\hline OLRS & 3.73 & 0.56 & -0.306 & 0.732 & 0.91 \\
\hline
\end{tabular}

Note. $T T E L=$ Tendency towards e-learning; $A F E L=$ Avoidance from e-learning; ELA = E-learning attitude; $C I S=$ Computer/Internet self-efficacy; $S D L=$ self-directed learning; $L C$ $=$ Learner control; $M F L=$ Motivation for learning; $O C S=$ Online communication self-efficacy; $O L R S=$ Online learning readiness.

According to the findings in Table 3 where average scores in e-learning attitude and readiness of the pre-service teachers were compared in terms of gender; a significant difference was identified in average scores of computer/Internet self-efficacy $[\mathrm{t}(517)=-2.669 ; \mathrm{p}<0.01]$; self-directed learning [t(517) $=-2.659 ; \mathrm{p}<0.01]$, learner control $[\mathrm{t}(517)=-1.992 ; \mathrm{p}<0.05]$, online communication self-efficacy $[\mathrm{t}(517)=-2.886 ; \mathrm{p}<0.01]$ and general average score of e-learning readiness $[\mathrm{t}(517)=-3.100 ; \mathrm{p}<0.01]$ on behalf of male candidate teachers. On the other hand; no statistically significant difference was found in average scores of motivation for learning $[\mathrm{t}(517)=-1.350 ; \mathrm{p}>0.05]$, tendency towards e-learning $[\mathrm{t}(517)=-0.908 ; \mathrm{p}>$ $0.05]$, avoidance from e-learning $[\mathrm{t}(517)=1.381 ; \mathrm{p}>0.05]$ and general average score of attitudes towards e-learning [t(517) $=-1.183 ; \mathrm{p}>0.05]$. 


\section{Macrothink}

Table 3. Comparison of pre-service teachers' e-learning attitudes and readiness according to gender variable

\begin{tabular}{|l|l|l|l|l|}
\hline & $\begin{array}{l}\text { Female }(\mathrm{n}=379) \\
\mathrm{M} \pm \mathrm{SD}\end{array}$ & $\begin{array}{l}\text { Male }(\mathrm{n}=140) \\
\mathrm{M} \pm \mathrm{SD}\end{array}$ & $\mathrm{t}(517)$ & $\mathrm{p}$ \\
\hline TTEL & $2.57 \pm 0.84$ & $2.65 \pm 0.97$ & -0.908 & 0.364 \\
\hline AFEL & $3.43 \pm 0.86$ & $3.31 \pm 0.91$ & 1.381 & 0.168 \\
\hline ELA & $2.57 \pm 0.82$ & $2.67 \pm 0.91$ & -1.183 & 0.238 \\
\hline CIS & $3.50 \pm 0.82$ & $3.75 \pm 0.99$ & -2.669 & $<0.01^{* *}$ \\
\hline$S D L$ & $3.65 \pm 0.64$ & $3.82 \pm 0.69$ & -2.659 & $<0.01^{* *}$ \\
\hline LC & $3.43 \pm 0.64$ & $3.58 \pm 0.82$ & -1.992 & $<0.05^{*}$ \\
\hline$M F L$ & $4.02 \pm 0.57$ & $4.10 \pm 0.67$ & -1.350 & 0.178 \\
\hline OCS & $3.74 \pm 0.80$ & $3.97 \pm 0.79$ & -2.886 & $<0.01^{* *}$ \\
\hline OLRS & $3.69 \pm 0.53$ & $3.86 \pm 0.63$ & -3.100 & $<0.01^{* *}$ \\
\hline
\end{tabular}

Note. TTEL $=$ Tendency towards e-learning; $A F E L=$ Avoidance from e-learning; ELA = E-learning attitude; $C I S=$ Computer/Internet self-efficacy; $S D L=$ self-directed learning; $L C$ $=$ Learner control; $M F L=$ Motivation for learning; OCS = Online communication self-efficacy; $O L R S=$ Online learning readiness.

When the pre-service teachers' attitudes towards e-learning and their readiness levels were examined in Table 4 in terms of academic departments, it was found that there were no significant differences in average scores of tendency towards e-learning $[\mathrm{F}(3,515)=0.769$; $p>0.05]$, avoidance from e-learning $[F(3,515)=0.185 ; p>0.05]$, general average score of attitudes towards e-learning $[\mathrm{F}(3,515)=0.228 ; \mathrm{p}>0.05]$, computer/Internet self-efficacy $[F(3,515)=1.279 ; p>0.05]$, self-directed learning $[F(3,515)=1.244 ; p>0.05]$, learner control $[F(3,515)=0.173 ; p>0.05]$, motivation for learning $[F(3,515)=0.381 ; p>0.05]$, online communication self-efficacy $[\mathrm{F}(3,515)=2.111 ; \mathrm{p}>0.05]$ and general average score of e-learning readiness $[\mathrm{F}(3,515)=0.577 ; \mathrm{p}>0.05]$. Accordingly; it may be argued that academic departments where the candidate teachers were taught did not have an important effect upon attitudes towards e-learning and readiness. 


\section{1) Macrothink}

Table 4. Comparison of pre-service teachers' e-learning attitudes and readiness according to deparment variable

\begin{tabular}{|l|l|l|l|l|l|l|}
\hline & $\begin{array}{l}\text { Turk. Lang. and Social Sci. } \\
(\mathrm{n}=206) \\
\mathrm{M} \pm \mathrm{SD}\end{array}$ & $\begin{array}{l}\text { Math. and Science } \\
(\mathrm{n}=163) \\
\mathrm{M} \pm \mathrm{SD}\end{array}$ & $\begin{array}{l}\text { English Language } \\
(\mathrm{n}=46) \\
\mathrm{M} \pm \mathrm{SD}\end{array}$ & $\begin{array}{l}\text { Phy. Edu. and Sports } \\
(\mathrm{n}=104) \\
\mathrm{M} \pm \mathrm{SD}\end{array}$ & $\mathrm{F}(3,515)$ & $\mathrm{p}$ \\
\hline TTEL & $2.52 \pm 0.87$ & $2.65 \pm 0.85$ & $2.57 \pm 0.91$ & $2.64 \pm 0.93$ & 0.769 & 0.512 \\
\hline AFEL & $3.40 \pm 0.89$ & $3.43 \pm 0.84$ & $3.35 \pm 0.96$ & $3.36 \pm 0.88$ & 0.185 & 0.906 \\
\hline ELA & $2.56 \pm 0.85$ & $2.61 \pm 0.81$ & $2.61 \pm 0.91$ & $2.64 \pm 0.88$ & 0.228 & 0.877 \\
\hline CIS & $3.52 \pm 0.87$ & $3.68 \pm 0.84$ & $3.54 \pm 1.04$ & $3.51 \pm 0.86$ & 1.279 & 0.281 \\
\hline SDL & $3.71 \pm 0.67$ & $3.71 \pm 0.61$ & $3.53 \pm 0.77$ & $3.74 \pm 0.65$ & 1.244 & 0.293 \\
\hline LC & $3.46 \pm 0.70$ & $3.46 \pm 0.63$ & $3.54 \pm 0.73$ & $3.45 \pm 0.78$ & 0.173 & 0.915 \\
\hline MFL & $4.05 \pm 0.63$ & $4.03 \pm 0.56$ & $3.99 \pm 0.65$ & $4.09 \pm 0.61$ & 0.381 & 0.767 \\
\hline OCS & $3.73 \pm 0.78$ & $3.85 \pm 0.77$ & $3.66 \pm 0.87$ & $3.92 \pm 0.85$ & 2.111 & 0.098 \\
\hline OLRS & $3.71 \pm 0.58$ & $3.76 \pm 0.52$ & $3.66 \pm 0.58$ & $3.76 \pm 0.57$ & 0.577 & 0.630 \\
\hline
\end{tabular}

Note. $T T E L=$ Tendency towards e-learning; $A F E L=$ Avoidance from e-learning; $E L A=$ E-learning attitude; $C I S=$ Computer/Internet self-efficacy; $S D L=$ self-directed learning; $L C$ $=$ Learner control; $M F L=$ Motivation for learning; $O C S=$ Online communication self-efficacy; $O L R S=$ Online learning readiness.

In Table 5, where pre-service teachers' average scores in attitudes towards e-learning and their readiness were compared according to age levels; it was identified that there were significant differences in the scores of tendency towards e-learning $[\mathrm{F}(2,516)=12.798 ; \mathrm{p}<$ $0.001]$, avoidance from e-learning $[\mathrm{F}(2,516)=7.086 ; \mathrm{p}<0.001]$ and general average score of attitudes towards e-learning $[\mathrm{F}(2,516)=10.334 ; \mathrm{p}<0.001]$, computer/Internet self-efficacy $[\mathrm{F}(2,516)=11.650 ; \mathrm{p}<0.001]$, self-directed learning $[\mathrm{F}(2,516)=10.445 ; \mathrm{p}<$ $0.001]$, learner control $[\mathrm{F}(2,516)=9.489 ; \mathrm{p}<0.001]$, motivation for learning $[\mathrm{F}(2,516)=$ $4.847 ; \mathrm{p}<0.01]$, online communication self-efficacy $[\mathrm{F}(2,516)=6.166 ; \mathrm{p}<0.01]$ and general average score of e-learning readiness $[\mathrm{F}(2,516)=13.337 ; \mathrm{p}<0.001]$. 
Table 5. Comparison of pre-service teachers' e-learning attitudes and readiness according to age variable

\begin{tabular}{|l|l|l|l|l|l|}
\hline & $\begin{array}{l}18-20(n=252) \\
\mathrm{M} \pm \mathrm{SD}\end{array}$ & $\begin{array}{l}21-23(n=208) \\
\mathrm{M} \pm \mathrm{SD}\end{array}$ & $\begin{array}{l}\geq 24(n=59) \\
\mathrm{M} \pm \mathrm{SD}\end{array}$ & $\mathrm{F}(2,516)$ & $\mathrm{p}$ \\
\hline TTEL & $2.44 \pm 0.79$ & $2.63 \pm 0.88$ & $3.06 \pm 1.04$ & 12.798 & $<0.001^{* * *}$ \\
\hline AFEL & $3.49 \pm 0.83$ & $3.39 \pm 0.87$ & $3.02 \pm 1.00$ & 7.086 & $<0.001^{* * *}$ \\
\hline ELA & $2.48 \pm 0.79$ & $2.62 \pm 0.84$ & $3.02 \pm 0.99$ & 10.334 & $<0.001^{* * *}$ \\
\hline CIS & $3.40 \pm 0.87$ & $3.66 \pm 0.83$ & $3.95 \pm 0.92$ & 11.650 & $<0.001^{* * *}$ \\
\hline SDL & $3.60 \pm 0.61$ & $3.73 \pm 0.68$ & $4.02 \pm 0.68$ & 10.445 & $<0.001^{* * *}$ \\
\hline LC & $3.35 \pm 0.67$ & $3.53 \pm 0.69$ & $3.75 \pm 0.74$ & 9.489 & $<0.001^{* * *}$ \\
\hline MFL & $4.00 \pm 0.56$ & $4.03 \pm 0.62$ & $4.27 \pm 0.66$ & 4.847 & $<0.01^{* *}$ \\
\hline OCS & $3.69 \pm 0.80$ & $3.86 \pm 0.76$ & $4.07 \pm 0.88$ & 6.166 & $<0.01^{* *}$ \\
\hline OLRS & $3.63 \pm 0.51$ & $3.77 \pm 0.56$ & $4.03 \pm 0.64$ & 13.337 & $<0.001^{* * *}$ \\
\hline
\end{tabular}

Note. TTEL $=$ Tendency towards e-learning; $A F E L=$ Avoidance from e-learning; ELA = E-learning attitude; $C I S=$ Computer/Internet self-efficacy; $S D L=$ self-directed learning; $L C$ $=$ Learner control; $M F L=$ Motivation for learning; OCS = Online communication self-efficacy; $O L R S=$ Online learning readiness.

According to the results of the Scheffe test performed to determine among which groups the difference existed; it was found that those aged $\geq 24$ years had higher average scores for a tendency towards e-learning and attitudes towards e-learning, as compared to those aged between 21 and 23 years and those aged between 18 and 20 years; whereas their avoidance from e-learning average scores were statistically and significantly lower. Accordingly; it was concluded that candidate teachers aged $\geq 24$ years demonstrated a more positive attitude towards e-learning than those candidate teachers who were younger. Moreover; it was understood that those candidate teachers aged $\geq 24$ years and those aged between 21 and 23 years considered themselves more self-efficient in computer/Internet self-efficacy and learner control as compared to those aged between 18 and 20 years. Those pre-service teachers aged $\geq 24$ years considered themselves self-efficient in self-directed learning and motivation for learning as compared to those aged between 21 and 23 years, and those aged between 18 and 20 years; and those aged $\geq 24$ years considered themselves more self-efficient in online communication self-efficacy as compared to those aged between 18 and 20 years. When participants' average scores in e-learning readiness were assessed in a general sense; there was found to be a significant difference in favour of older pre-service teachers among all age groups. Accordingly; it may be suggested that age plays a role in important role both in attitudes towards e-learning and readiness.

In Table 6, correlations between pre-service teachers' attitudes towards e-learning and their 
readiness levels were evaluated and it was noted that there was a moderate, positive and significant correlation between tendency towards e-learning and computer/Internet self-efficacy $(r=0.30)$, self-directed learning $(r=0.41)$, learner control $(r=0.53)$, online communication self-efficacy $(r=0.33)$ and e-learning readiness $(r=0.45)$; but a low and positive correlation was detected between a tendency towards e-learning and motivation for learning $(\mathrm{r}=0.24)$ while a moderate, negative and significant correlation existed between avoidance from e-learning and self-directed learning $(r=-0.34)$, learner control $(r=-0.50)$, online communication self-efficacy $(r=-0.30)$ and e-learning readiness $(r=-0.40)$; but a low, negative and significant correlation was seen between avoidance from e-learning and computer/Internet self-efficacy $(\mathrm{r}=-0.26)$ and motivation for learning $(\mathrm{r}=-0.19)$. Also, a moderate, positive and significant correlation was found between the participant candidate teachers' e-learning general attitudes and self-directed learning $(r=0.39)$, learner control $(r=$ $0.53)$, online communication self-efficacy $(r=0.32)$ and e-learning readiness $(r=0.44)$, while a low, positive and significant correlation was detected between e-learning general attitudes and computer/Internet self-efficacy $(r=0.29)$, and motivation for learning $(r=0.22)$.

Table 6. The relationship between pre-service teachers' e-learning readiness and e-learning attitudes

\begin{tabular}{|l|l|l|l|l|l|l|l|l|l|}
\hline & \multicolumn{9}{|c|}{ Bivariate Correlations (r) } \\
\cline { 2 - 11 } & $\mathbf{1}$ & $\mathbf{2}$ & $\mathbf{3}$ & $\mathbf{4}$ & $\mathbf{5}$ & $\mathbf{6}$ & $\mathbf{7}$ & $\mathbf{8}$ & $\mathbf{9}$ \\
\hline 1-TTEL & 1.00 & & & & & & & & \\
\hline 2-AFEL & $-0.87^{* *}$ & 1.00 & & & & & & & \\
\hline 3-ELA & $0.97^{* *}$ & $-0.97^{* *}$ & 1.00 & & & & & & \\
\hline $4-C I S$ & $0.30^{* *}$ & $-0.26^{* *}$ & $0.29^{* *}$ & 1.00 & & & & & \\
\hline $5-S D L$ & $0.41^{* *}$ & $-0.34^{* *}$ & $0.39^{* *}$ & $0.43^{* *}$ & 1.00 & & & & \\
\hline $6-L C$ & $0.53^{* *}$ & $-0.50^{* *}$ & $0.53^{* *}$ & $0.38^{* *}$ & $0.65^{* *}$ & 1.00 & & & \\
\hline $7-M F L$ & $0.24^{* *}$ & $-0.19^{* *}$ & $0.22^{* *}$ & $0.36^{* *}$ & $0.65^{* *}$ & $0.54^{* *}$ & 1.00 & & \\
\hline 8-OCS & $0.33^{* *}$ & $-0.30^{* *}$ & $0.32^{* *}$ & $0.56^{* *}$ & $0.57^{* *}$ & $0.49^{* *}$ & $0.57^{* *}$ & 1.00 & \\
\hline 9-OLRS & $0.45^{* *}$ & $-0.40^{* *}$ & $0.44^{* *}$ & $0.70^{* *}$ & $0.86^{* *}$ & $0.76^{* *}$ & $0.79^{* *}$ & $0.81^{* *}$ & 1.00 \\
\hline
\end{tabular}

Note. $T T E L=$ Tendency towards e-learning; $A F E L=$ Avoidance from e-learning; $E L A=$ E-learning attitude; $C I S=$ Computer/Internet self-efficacy; $S D L=$ self-directed learning; $L C$ $=$ Learner control; $M F L=$ Motivation for learning; OCS = Online communication self-efficacy; $O L R S=$ Online learning readiness. ${ }^{* *} \mathrm{p}<0.01$. 
Table 7. Simple linear regression analysis for predicting pre-service teachers' attitudes towards e-learning

\begin{tabular}{|l|l|l|l|l|l|}
\hline & $\mathrm{B}$ & $\mathrm{SE}(\mathrm{B})$ & $\beta$ & $\mathrm{t}$ & $\mathrm{p}$ \\
\hline Constant & 0.18 & 0.22 & - & 0.480 & 0.631 \\
\hline E-learning Readiness & 0.67 & 0.06 & 0.44 & 11.156 & $<0.001^{* * *}$ \\
\hline $\begin{array}{l}\mathrm{R}=0.440 ; \mathrm{R}^{2}=0.194 . \\
\mathrm{F}(1,517)=124.460 ; \mathrm{p}<0.0001 .\end{array}$ & & & \\
\hline
\end{tabular}

As a result of the simple linear regression analysis shown in Table 7, it was concluded that learning attitude was moderately and significantly correlated with e-learning readiness $(\mathrm{R}=$ $\left.0.44 ; \mathrm{R}^{2}=0.19 ; \mathrm{p}<0.001\right)$. Accordingly; readiness for e-learning accounted for $19 \%$ of the total variance. When standardized beta coefficient and $t$ value were examined; it may be assumed that readiness for e-learning was an important predictor of attitudes towards e-learning $(\beta=0.44 ; \mathrm{t}=11.156 ; \mathrm{p}<0.001)$.

\section{Discussion}

\subsection{Pre-Service Teachers'Attitudes Towards E-Learning}

In the current study, it may be suggested as a general conclusion that candidate teachers were closer to having a negative attitude towards e-learning, and it was observed that their general attitude scores were below the average (Table 2). Accordingly; it may be assumed that candidate teachers' views about the assumptions that e-learning facilitated learning, enhanced success and productivity, and that e-learning was entertaining, were negative. Additionally, the study results pointed out that pre-service teachers were of the opinion that -as far as the items included in the attitudes towards e-learning scale were concerned- academic assessment in e-learning could not be performed properly and accurately, lack of face-to-face interaction in e-learning would affect learning negatively, they would not benefit enough from teacher assistance, and e-learning would influence socialization adversely.

Tedmem (2020) stated that lack of Internet access and technological sources influenced distance learning in higher education negatively during the pandemic; applied courses, laboratory studies and applied researches were interrupted and the distance education competence of academic personnel affected the quality of teaching. When the results in the emerging literature of studies carried out during COVID-19 pandemic were reviewed, it was concluded that pre-service teachers showed negative attitudes towards distance education, were unwilling and regarded themselves as lacking competence to offer online distance education in the future, and believed that teaching courses online was not the future of the education (Karatepe, Küçükgençay, \& Peker, 2020). In another study; Abbasi, Ayoob, Malik, and Memon (2020) performed a study with students of medicine and dentistry faculty in Pakistan, and concluded that most of the students had a negative perception on e-learning, felt that the effect of e-learning upon learning was rather low, and preferred face-to-face 
education. As a result of the study of Diab and Elgahsh (2020) conducted with nursing students in Egypt; it was identified that nearly two-thirds of the students showed a negative attitude towards e-learning. The researchers attributed these outcomes to the possibility that they might have been caused by the sudden transition to online learning from face-to-face learning during the pandemic, so that therefore students developed a resistance and refusal approach. According to the results of the study that Altuntaş Y1lmaz (2020) carried out with students of physiotherapy and rehabilitation departments during COVID-19 period, the majority of the students expressed that distance education was unproductive in teaching both practical courses and theoretical courses. Again, a great proportion of the students reported that they wanted to continue their courses in the form of formal education when education returned to pre-pandemic normal after the pandemic. On the other hand, Radha et al. (2020) conducted a study with students joining from different universities and schools, and came to the conclusion that students generally favored e-learning, were willing to undertake e-learning, and felt that e-learning improved their individual study skills and was useful. However, the same study reported that most of the students found face to face learning (classroom environments) more effective in terms of both applied skill teaching and general learning environment preference. In this sense; the findings obtained from this study parallel with those of other studies carried out during COVID-19 period.

\subsection{Pre-Service Teachers'E-Learning Readiness}

It has been stated that the participating pre-service teachers' e-learning readiness levels in this study were above the average and that they considered themselves ready for e-learning (Table 2 ). In this context, it may be argued that the participating pre-service teachers considered themselves able in regard to e-learning information and communication technologies, determining learning needs and objectives, determining necessary learning sources, choosing and using suitable learning strategies, managing their own learning processes, having learning motivation and connecting online communication. These results were in line with those of studies conducted prior to the pandemic (Çakır \& Horzum, 2015; Kırmız1, 2015; Adnan \& Boz-Yaman, 2017; Obi et al., 2018; D. S. Öztürk, F. Öztürk, \& Özen, 2018; Y1lmaz, Sezer, \& Yurdugül, 2019; Mavi \& Erçağ, 2020). Additionally; when the results of the studies conducted during COVID-19 pandemic were examined, similar results were encountered. For example; in the study that Türkmen, Aşç1, and Zor (2020) carried out with students who studied at vocational high school, it was found that students generally showed e-learning readiness above the average. In the study that Adnan and Anwar (2020) conducted with undergraduate and postgraduate students, more than half of the students considered themselves competent in using computer and communicating easily for e-learning. Likewise; the study of Chung, Subramaniam, and Dass (2020), carried out with university students studying in Malaysia, argued that students generally showed online learning readiness at a moderate level. Meanwhile; the participants in the current study considered themselves self-sufficient in learning motivation at the highest level, while learner control and computer/Internet self-efficacy at the lowest level. Similar study results were also seen in the studies of Çakır and Horzum (2015) and Torun (2020). However; results obtained from other studies differed. For example; the results of research by Kırmızı (2015), conducted with 
students who studied at a Department of English Language and Literature, identified that students found themselves able in self-directed learning at the highest level, whereas at the lowest level in learner control. This finding may have been obtained because only students from the English Language and Literature department were included in the study. In the study that Alsancak Sirakaya, and Yurdugül (2016) carried out with pre-service teachers at a university in Turkey, it was found that candidate teachers' online communication and computer/Internet self-efficacy were lower than their learner control and motivation. The study that Sakal (2017) carried out with the participation of students from different faculties of a university in Turkey reported that students' computer/Internet self-efficacy was lower than other factors. The study of Y1lmaz, Sezer, and Yurdugül (2019) showed that these university students' computer self-efficacy and motivation for learning were moderate, while their Internet, online communication, self-directed learning self-efficacy and learning control self-efficacy were higher. In the study of Türkmen et al. (2020) that was conducted with students of vocational high school, it was concluded that students felt ready in having Internet self-efficacy at the highest level, while their motivation for e-learning was at the lowest level. When results of the foreign studies in which students of different countries participated were investigated, Chung et al. (2020) reported that their students in Malaysia considered themselves able in computer/Internet self-efficacy the most whereas in learning control the least. Allam, Hassan, Mohideen, Ramlan, and Kamal (2020) conducted a study with undergraduate students studying in Malaysia and reported that students had a high level of computer/Internet literacy while their self-directed learning and learning motivation levels were low.

\subsection{Gender and Pre-Service Teachers'Attitudes Towards E-Learning}

In the current study; no difference existed in attitudes towards e-learning in terms of pre-service teachers' gender (Table 3), which was consistent with the results of other studies in the literature (Kar, Saha, \& Mondal, 2014; Topal, 2016; Korucu, Usta, \& Çoklar, 2019; Altuntaş Y1lmaz, 2020; Karadağ \& Yücel, 2020; Mavi \& Erçă̆, 2020). However; the study of Haznedar (2012), which was carried out with university students from different universities prior to the pandemic argued that male students' attitudes towards e-learning were higher than those of female students; the study of Buluk and Eşitti (2020) which was conducted with undergraduate students attending the department of tourism management during COVID-19 pandemic, found that male students were more satisfied with distance education courses as compared to female students, and attended the activities of distance education courses more. And the study of Aktaş, Büyüktaş, Gülle, and Yıldız (2020) identified that male students preferred courses to be offered through distance education more than did female students during both the COVID-19 pandemic period and the previous normal period. Similarly, Diab and Elgahsh (2020) stated that male students had more positive attitudes towards e-learning than female students. However; there are also limited study results reporting that female students' online learning satisfaction levels were higher than male students (Chung et al., 2020). In the present study, although there was not a significant difference, male pre-service teachers were somewhat more inclined to e-learning whereas female candidate teachers were more inclined to have a negative attitude towards e-learning; which concurred with the 
literature (Table 3).

\subsection{Gender and Pre-Service Teachers' E-Learning Readiness}

It was determined in the current study that the participating male pre-service teachers regarded themselves as more able in computer/Internet self-efficacy, self-directed learning, learning control, online communication self-efficacy and general e-learning readiness than did female pre-service teachers, although no significant difference was seen in e-learning motivation. Another result of the present study was that, likewise, male candidate teachers' average scores were higher (Table 3). The results which turned out to be in favour of the male students in terms of e-learning readiness showed in line with the results of other studies (Haznedar, 2012; Sakal, 2017; Olcay, Döş, Sürme, \& Düzgün, 2018; Y1lmaz et al., 2019; İbili, 2020). On the other hand, some other studies reported no significant difference in students' e-learning readiness in terms of gender. For example, in the studies of Adnan and Boz-Yaman (2017) carried out with engineering students, or those, of Hung et al. (2010) conducted with university students studying in Taiwan or of Chung et al. (2020) carried out with university students studying in Malaysia during the COVID-19 pandemic, it was determined that gender did not affect e-learning readiness significantly.

\subsection{Academic Departments and Pre-Service Teachers' Attitudes Towards E-Learning}

In this study, that was conducted with the participation of candidate teachers from Necatibey Education Faculty and Sports Sciences Faculty of Balikesir University, no significant differences were found in attitudes towards e-learning in terms of the academic departments where the pre-service teachers studied (Table 4). In the literature, there are studies with similar and different results. For example, as a result of the study by Topal (2016) which was conducted with the participation of students from different faculties of a university and examined students' satisfaction levels in e-courses, it was determined that academic departments played a significant role in e-learning satisfaction levels; and that those whose satisfaction level was the lowest were the students of the Education faculty. In the study of Öztürk et al. (2018) that reviewed pre-service teachers' e-learning readiness and satisfaction levels, it was identified that there was a significant difference in satisfaction levels of students in terms of the academic departments that they attended. According to study results, students who studied at the departments of history-geography and philosophy, sociology and psychology were more satisfied with e-learning than were those students who studied at the department of social sciences teaching. The study of Korucu et al. (2019), carried out with students attending tourism and education faculties of two different universities, investigated attitudes towards mobile learning and determined that students studying at education faculties had higher attitudes towards mobile learning than did students studying at tourism faculties. But the study of Hergüner et al. (2020), that was conducted with the participation of students studying physical education and sports, law education and English language education from different universities of Turkey during COVID-19 pandemic, reported that the academic departments where the students studied did not have a significant effect upon their attitudes, which in line with the results of the current study. 
4.6 Academic Departments and Pre-Service Teachers' E-Learning Readiness

This study found that pre-service teachers were ready for e-learning at similar levels in terms of both the e-learning readiness subscales and the total e-learning readiness scale (Table 4). Therefore, this result of the current study was similar to that of the study carried out with medicine faculty students during COVID-19 pandemic (Neupane, Sharma, \& Joshi, 2020), and that of another study done with the participation of students from different faculties (Hergüner et al., 2020). According to the result of the study of İbili (2020) conducted with faculty of health sciences students during COVID-19 period, it was found that the academic departments where the students studied had a significant effect upon their readiness levels. Similarly, when previous studies were examined, it was also found to have been reported that e-learning readiness differed in terms of academic departments (Alsancak S1rakaya \& Yurdugül., 2016; Sakal, 2017; Öztürk et al., 2018; Y1lmaz et al., 2019).

\subsection{Age and Pre-Service Teachers' Attitudes Towards E-Learning}

According to the result of the current study it was concluded that there was a significant difference in candidate teachers' attitudes towards e-learning in terms of age level (Table 5). As a result of the analysis performed, it was found that those aged $\geq 24$ years favored e-learning more, in terms of their tendency towards e-learning and attitudes towards e-learning, as compared to those aged between 21 and 23 years, and those aged between 18 and 20 years. Similarly; the average scores for avoidance from e-learning for those aged $\geq 24$ years was found to be statistically and significantly lower than those of students who were younger. Consequently; it was found that pre-service teachers aged $\geq 24$ years demonstrated a more positive attitude towards e-learning than did those candidate teachers who were younger. In the study of Uslusoy (2017), where higher education students' attitudes towards distance education were studied, older students showed more positive attitudes and perceptions as compared to younger students. Likewise, Etlioğlu (2019) conducted a study with university students from different universities in Turkey, and reported that positive attitude towards e-learning of the students with high age levels were higher as compared to other students, while the negative attitudes towards e-learning of the younger students were higher. Finding further results similar to the current study, Diab and Elgahsh (2020) identified that students with low age levels had more negative attitudes towards e-learning than those students with high age levels. On the contrary, however, there are in literature results of some studies concluding that age level was not an effective factor in attitudes towards e-learning. The study of Suri and Sharma (2013), carried out with students of a university in India, and the study of Adewole-Odeshi (2014) of the participation of the students studying at universities in Nigeria came to the conclusion that no difference existed in attitudes towards e-learning in terms of age.

\subsection{Age and Pre-Service Teachers' E-Learning Readiness}

In the current study; it was found that candidate teachers' ages were an effective factor in correlating with readiness for e-learning levels (Table 5). Accordingly; it was seen that the candidate teachers aged $\geq 24$ years and those aged between 21 and 23 years considered themselves more competent in computer/Internet self-efficacy and learner control as 
compared to those aged between 18 and 20 years; the pre-service teachers aged $\geq 24$ years found themselves more able in self-directed learning and motivation for learning as compared to those aged between 21 and 23 years and those aged between 18 and 20 years; and the candidate teachers aged $\geq 24$ years regarded themselves as more competent in online communication self-efficacy than those aged between 18 and 20 years. When participants' e-learning readiness average scores were assessed in a general sense, a significant difference was determined in favour of older pre-service teachers among all age groups. However, when previous studies in the literature were investigated, results that were contrary to the current study were found. For example; in the study by Çiğdem and Yıldırım (2014), carried out with students of vocational high school; and in the study of Çakır and Horzum (2015), conducted with pre-service teachers from different universities; and in the study of Korkmaz, Çakır, and Tan (2015), conducted with students studying an academic program through distance education of a university in Turkey, all concluded that students' age levels did not have an effect upon their e-learning readiness. Therefore; we are of the opinion that, in order explore the reasons for these differences in study results, more studies to investigate the correlation between students' age and e-learning readiness levels should be conducted.

\subsection{Correlations Between E-Learning Attitude and Readiness}

According to results of correlation analyses performed to find the correlation between pre-service teachers' attitudes towards e-learning and readiness, in the current study a positive correlation was determined between scores for the tendency in favor of e-learning and attitudes towards e-learning in general, and e-learning readiness; whereas a negative correlation was understandably determined between avoidance from e-learning and e-learning readiness (Table 6). Consequently it was noted that a moderate, positive and significant correlation was determined between a tendency towards e-learning and computer/Internet self-efficacy, self-directed learning, learner control, online communication self-efficacy and e-learning readiness, but that a low and positive correlation was found between a tendency towards e-learning and motivation for learning, while a moderate, negative and significant correlation existed between avoidance from e-learning and self-directed learning, learner control, online communication self-efficacy and e-learning readiness. However, a low, negative and significant correlation was seen between avoidance from e-learning and computer/Internet self-efficacy and motivation for learning.

In addition; a moderate and positive correlation was found between the participant candidate teachers' e-learning general attitudes and self-directed learning, learner control, online communication self-efficacy and e-learning readiness but a low, positive and significant correlation was determined between e-learning general attitudes and computer/Internet self-efficacy and motivation for Learning. Meanwhile; as a result of the simple linear regression analysis, it was found that learning attitude was moderately and significantly correlated with e-learning readiness (Table 7). Accordingly, e-learning readiness explained $19 \%$ of the total variance. When standardized beta coefficient and t value were examined; it was concluded that readiness for e-learning was an important predictor of attitudes towards e-learning. Hence; we are of the opinion that educational institutions should provide the students with the necessary knowledge and skills that will prepare them for e-learning so that 
e-learning can be adopted.

It is suggested that the terms of attitude and readiness are close to each other in their definitions, and that students' attitudes towards a certain course will positively or negatively be influenced by their readiness (Ocak \& Karakuş, 2014). According to Thorndike's Readiness Law, if one feels ready to accomplish a task, he/she will be satisfied to do it and doing the activity gives him/her happiness. On the contrary; if one does not feel ready to accomplish the task and is forced to do it, they feel disturbance (Senemoğlu, 2018). According to Neupane et al. (2020), e-learning readiness constitutes the principal and key component of online learning. Endorsing the fact that the results of the current study were in line with the literature, Jena (2016), and Hergüner et al. (2020) reported finding that a positive correlation existed between students' online learning attitudes and their readiness levels. Some other studies identified significant correlations between students' e-learning readiness and their satisfaction. For example, Öztürk et al. (2018) reported a positive correlation between pre-service teachers' e-learning readiness and satisfaction levels. In the study of Y1lmaz (2017), students' readiness for e-learning turned out to be a significant predictor of their course satisfaction and motivations in flipped classroom models. Wei and Chou (2020) conducted a study with university students and reported that students' computer/Internet self-efficacy played a significant role in course satisfaction. Topal (2016) reported a positive and significant correlation between students' satisfaction and readiness levels. Students' e-learning readiness levels were to be predicting their satisfaction positively. Rhema and Miliszewska (2014) carried out a study with engineering students in Libya, and found skills in technology to be predictor of information and communication technologies and attitudes towards e-learning. Rizun and Strzelecki (2020) conduct a study with university students who studied in Poland during the COVID-19 period, and concluded that students' both perceived easiness and perceived benefits in distance education positively predicted their attitudes and tendencies towards using distance education. Diab and Elgahsh (2020) found a high negative correlation between barriers to e-learning among nursing students while they were participating in e-learning, and their attitudes towards e-learning. Peytcheva-Forsyth, Yovkova and Aleksieva (2018) reported that students' abilities and experiences in information and communication technologies were considerably influenced by their online learning attitudes. In sum, it was seen in the light of all of these findings that the correlations found in the present study between attitudes towards e-learning and e-learning readiness were in line with the literature.

\section{Suggestions}

One of the key limitations of the study was that the participants were recruited only from the pre-service teachers of Balıkesir University. Therefore, it is necessary that prospective studies be carried out with larger samples. In addition, another limitation of the study was that the participant candidate teachers' courses were taught using only Microsoft Teams as a distance education tool.

Considering the nature of the teaching profession and the structure of undergraduate teaching programs, that candidate teachers feel ready for e-learning but, at the same time, feel closer to 
negative attitudes, may cause them to regard e-learning settings as less productive than face-to-face teaching in their future professional lives. It may be a discussion point that the emergent and compulsory transition to distance education from face-to-face education followed by ambiguity about when pre-COVID-19 normal will resume, may have led to prejudice against e-learning; which, perhaps, made candidate teachers have negative attitudes. To prevent this, it is important that university instructors should design course materials and contents in a way that will draw the attention of students and to meet their wishes and professional expectations. Similarly; it is considered essential that student-centered new teaching methods and approaches be introduced into the courses to be taught through distance education methods and instructors are encouraged about how instructor-student interaction and student-student interaction can be enhanced in e-learning settings, and about how various student-centered assessment and evaluation approaches can be incorporated into the process. We have no doubt research and application centers of universities bear important associated responsibilities in this matter. Consistently student feedbacks about distance education processes should be taken, failing aspects should be corrected and distance education policies, strategies, aims and objectives should be identified at the university and/or faculty level.

In view of the fact that distance education will be an indispensable component of face-to-face education by either supporting it or replacing it in near future; it is essential that both students' and instructors' levels of readiness for and attitudes towards e-learning should be examined and responsive actions should be taken wherever it is necessary. Considering the fact that today's candidate teachers will enter the teaching profession as teachers in the future; their views of distance education will inevitably affect their professional lives.

\section{References}

Abbasi, S., Ayoob, T., Malik, A., \& Memon, S. I. (2020). Perceptions of Students Regarding E-learning During COVID-19 at A Private Medical College. Pakistan Journal of Medical Sciences, 36(COVID19-S4). https://doi.org/10.12669/pjms.36.COVID19-S4.2766

Adewole-Odeshi, E. (2014). Attitude of Students Towards E-learning in South-West Nigerian Universities: An Application of Technology Acceptance Model. Library Philosophy and Practice, 2014(1).

Adnan, M., \& Anwar, K. (2020). Online Learning amid the COVID-19 Pandemic: Students' Perspectives. Journal of Pedagogical Sociology and Psychology, 2(1), 45-51. https://doi.org/ 10.33902/JPSP.2020261309

Adnan, M., \& Boz-Yaman, B. (2017). Mühendislik Öğrencilerinin E-Öğrenmeye Dair Beklenti, Hazır Bulunuşluk ve Memnuniyet Düzeyleri. Turkish Journal of Computer and Mathematics Education, 8(2), 218-243. https://doi.org/10.16949/turkbilmat.280165

Ağır, F., Gür, H., \& Okçu, A. (2007). Uzaktan Eğitime Karşı Tutum Ölçeği Geliştirmeye Yönelik Geçerlilik ve Güvenirlik Çalışması. Education Sciences, 3(2), 128-139.

Aixia, D., \& Wang, D. (2011). Factors Influencing Learner Attitudes Toward E-learning and Development of E-learning Environment Based on the Integrated E-learning Platform. 
International Journal of e-Education, e-Business, e-Management and e-Learning, 1(3), 264-268. https://doi.org/10.7763/IJEEEE.2011.V1.43

Aktaş, Ö., Büyüktaş, B., Gülle, M., \& Yıldız, M. (2020). COVID-19 Virüsünden Kaynaklanan İzolasyon Günlerinde Spor Bilimleri Öğrencilerinin Uzaktan Eğitime Karş1 Tutumları. Sivas Cumhuriyet Üniversitesi Spor Bilimleri Dergisi, 1(1), 1-9.

Alawamleh, M., Al-Twait, L. M., \& Al-Saht, G. R. (2020). The Effect of Online Learning on Communication between Instructors and Students during COVID-19 Pandemic. Asian Education and Development Studies, in press. https://doi.org/10.1108/AEDS-06-2020-0131

Aljawarneh, S. A. (2020). Reviewing and Exploring Innovative Ubiquitous Learning Tools in Higher Education. Journal of Computing in Higher Education, 32, 57-73. https://doi.org/ 10.1007/s12528-019-09207-0

Allam, S. N. S., Hassan, M. S., Mohideen, R. S., Ramlan, A. F., \& Kamal, R. M. (2020). Online Distance Learning Readiness during COVID-19 Outbreak among Undergraduate Students. International Journal of Academic Research in Business and Social Sciences, 10(5), 642-657. https://doi.org/10.6007/IJARBSS/v10-i5/7236

Alsancak Sırakaya, D., \& Yurdugül, H. (2016). Öğretmen Adaylarının Çevrimiçi Öğrenme Hazır Bulunuşluluk Düzeylerinin İncelenmesi: Ahi Evran Üniversitesi Örneği. Journal of Kirsehir Education Faculty, 17(1), 185-200.

Altuntaş Yılmaz, N. (2020). Yükseköğretim Kurumlarında COVID-19 Pandemisi Sürecinde Uygulanan Uzaktan Eğitim Durumu Hakkında Öğrencilerin Tutumlarının Araştırılması: Fizyoterapi ve Rehabilitasyon Bölümü Örneği. Necmettin Erbakan Üniversitesi Sağllk Bilimleri Fakültesi Dergisi, 3(1), 15-20.

Artino Jr., A. R. (2009). Online Learning: Are Subjective Perceptions of Instructional Context Related to Academic Success? The Internet and Higher Education, 12(3-4), 117-125. https://doi.org/10.1016/j.iheduc.2009.07.003

Aşılıoğlu, B., Murat, M., \& Demir, R. (2018). Bağlaşımcılık ve Edimsel Koşullanma. In B. Oral (Ed.), Öğrenme Öğretme Kuram ve Yaklaşımları (4th ed.). Ankara: Pegem Akademi.

Borotis, S., \& Poulymenakou, A. (2004). E-learning Readiness Components: Key Issues to Consider Before Adopting E-learning Interventions. In J. Nall \& R. Robson (Eds.), Proceedings of E-learn 2004-World Conference on E-learning in Corporate, Government, Healthcare, and Higher Education (pp. 1622-1629). Washington, DC, USA: Association for the Advancement of Computing in Education (AACE). Retrieved from https://www.learn techlib.org/primary/p/11555

Buluk, B., \& Eşitti, B. (2020). Koronavirüs (COVID-19) Sürecinde Uzaktan Eğitimin Turizm Lisans Öğrencileri Tarafından Değerlendirilmesi. Journal of Awareness, 5(3), 285-298. https://doi.org/10.26809/joa.5.021

Büyüköztürk, Ş. (2018). Sosyal Bilimler için Veri Analizi El Kitabı (24th ed.). Ankara: Pegem Akademi. https://doi.org/10.14527/9789756802748 
Chung, E., Subramaniam, G., \& Dass, L. C. (2020). Online Learning Readiness among University Students in Malaysia amidst COVID-19. Asian Journal of University Education, 16(2), 46-58. https://doi.org/10.24191/ajue.v16i2.10294

Çakır, Ö., \& Horzum, M. B. (2015). Öğretmen Adaylarının Çevrimiçi Öğrenmeye Hazır Bulunuşluk Düzeylerinin Çeşitli Değişkenler Açısından İncelenmesi. Eğitimde Kuram ve Uygulama, 11(1), 1-15.

Çiğdem, H., \& Yıldırım, O. G. (2014). Effects of Students' Characteristics on Online Learning Readiness: A Vocational College Example. Turkish Online Journal of Distance Education, 15(3), 80-93. https://doi.org/10.17718/tojde.69439

Dada, D. (2006). E-readiness for Developing Countries: Moving the Focus from the Environment to the Users. The Electronic Journal on Information Systems in Developing Countries, 27(6), 1-14. https://doi.org/10.1002/j.1681-4835.2006.tb00183.x

Demir, O. (2015). The Investigation of E-learning Readiness of Students and Faculty Members: Hacettepe University, Faculty of Education Example (Master's Thesis, Hacettepe University, Ankara).

DeVaney, T. A. (2010). Anxiety and Attitude of Graduate Students in On-Campus vs. Online Statistics Courses. Journal of Statistics Education, 18(1), 1-15. https://doi.org/10.1080/ 10691898.2010.11889472

Dhawan, S. (2020). Online Learning: A Panacea in the Time of COVID-19 Crisis. Journal of Educational Technology Systems, 49(1), 5-22. https://doi.org/10.1177/0047239520934018

Diab, G. M. A. E. H., \& Elgahsh, N. F. (2020). E-learning during COVID-19 Pandemic: Obstacles Faced Nursing Students and its Effect on their Attitudes while Applying It. American Journal of Nursing, 9(4), 295-309. https://doi.org/10.11648/j.ajns.20200904.33

Egbo, O. P., Okoyeuzu, C. R., Ifeanacho, I. C., \& Onwumere, J. U. (2011). Gender Perception and Attitude Towards E-learning: A Case of Business Students, University of Nigeria. International Journal of Computer Application, 1(2), 135-148.

Ergün, E., \& Kurnaz Adıbatmaz, F. B. (2020). Exploring the Predictive Role of E-learning Readiness and E-learning Style on Student Engagement. Open Praxis, 12(2), 175-189. https://doi.org/10.5944/openpraxis. 12.2.1072

Erkut, E. (2020). COVID-19 Sonrası Yükseköğretim. Yükseköğretim Dergisi, 10(2), 125-133. https://doi.org/10.2399/yod.20.002

Etlioğlu, M. (2019). E-Öğrenmede Öğrenci Tutumu ve Akademik Başarı Arasındaki İlişkide Öğrenci Duyuşsal Özelliklerinin Aracılık Rolünün İncelenmesi (Doctoral Thesis, Selçuk Üniversitesi, Konya).

Frehywot, S., Vovides, Y., Talib, Z., Mikhail, N., Ross, H., Wohltjen, H., ... Scott, J. (2013). E-learning in Medical Education in Resource Constrained Low- and Middle-Income Countries. Human Resources for Health, 11(4), 1-15. https://doi.org/10.1186/1478-4491-11-4 
Galy, E., Downey, C., \& Johnson, J. (2011). The Effect of Using E-learning Tools in Online and Campus-Based Classrooms on Student Performance. Journal of Information Technology Education: Research, 10(1), 209-230. https://doi.org/10.28945/1503

George, D., \& Mallery, M. (2010). SPSS for Windows Step by Step: A Simple Guide and Reference (10th ed.). Boston, MA: Pearson.

Gros, B., \& García-Peñalvo, F. J. (2016). Future Trends in the Design Strategies and Technological Affordances of E-learning. In M. Spector, B. B. Lockee, \& M. D. Childress (Eds.), Learning, Design, and Technology. An International Compendium of Theory, Research, Practice, and Policy (pp. 1-23). Switzerland: Springer International Publishing. https://doi.org/10.1007/978-3-319-17727-4_67-1

Haznedar, Ö. (2012). Üniversite Öğrencilerinin Bilgi ve İletişim Teknolojileri Becerilerinin ve E-Öğrenmeye Yönelik Tutumlarının Farklı Değişkenler Açısından Incelenmesi (Doctoral Thesis, Dokuz Eylül Üniversitesi, İzmir).

Haznedar, Ö., \& Baran, B. (2012). Eğitim Fakültesi Öğrencileri için E-Öğrenmeye Yönelik Genel Bir Tutum Ölçeği Geliştirme Çalışması. Eğitim Teknolojisi Kuram ve Uygulama, 2(2), 42-59. https://doi.org/10.17943/etku.84225

Hergüner, G., Son, S. B., Son, S. H., \& Dönmez, A. (2020). The Effect of Online Learning Attitudes of University Students on their Online Learning Readiness. TOJET: The Turkish Online Journal of Educational Technology, 19(4), 102-110.

Hong, J. C., Tai, K. H., Hwang, M. Y., Kuo, Y. C., \& Chen, J. S. (2017). Internet Cognitive Failure Relevant to Users' Satisfaction with Content and Interface Design to Reflect Continuance Intention to Use A Government E-learning System. Computers in Human Behavior, 66, 353-362. https://doi.org/10.1016/j.chb.2016.08.044

Horzum, M. B., Demir Kaymak, Z., \& Güngören, O. C. (2015). Structural Equation Modeling towards Online Learning Readiness, Academic Motivations, and Perceived Learning. Educational Sciences: Theory \& Practice, 15(3), 759-770. https://doi.org/ 10.12738/estp.2015.3.2410

Hung, M. L., Chou, C., Chen, C. H., \& Own, Z. Y. (2010). Learner Readiness for Online Learning: Scale Development and Student Perceptions. Computers \& Education, 55(3), 1080-1090. https://doi.org/10.1016/j.compedu.2010.05.004

İbili, E. (2020). Examination of Health Science University Students' Level of Readiness for E-learning. International Online Journal of Education and Teaching, 7(3), 1010-1030. Retrieved from https://iojet.org/index.php/IOJET/article/view/868

İlhan, M., \& Çetin, B. (2013). Çevrimiçi Öğrenmeye Yönelik Hazır Bulunuşluk Ölçeği’nin (ÇÖHBÖ) Türkçe Formunun Geçerlik ve Güvenirlik Çalışması. Eğitim Teknolojisi Kuram ve Uygulama, 3(2), 72-101. https://doi.org/10.14686/201321984

Jena, R. K. (2016). Investigating the Interrelation between Attitudes, Learning Readiness, and Learning Styles Under Virtual Learning Environment: A Study among Indian Students. 
Behaviour \& Information Technology, 35(11), 946-957. https://doi.org/10.1080/0144929X. 2016.1212930

Kamarulzaman, Y., Madun, A., \& Ghani, F. A. (2011). Attitude towards E-learning among Students: Evidence from a Malaysian Public University. British Journal of Arts and Social Sciences, 3(2), 132-142.

Kar, D., Saha, B., \& Mondal, B. C. (2014). Attitude of University Students Towards E-learning in West Bengal. American Journal of Educational Research, 2(8), 669-673. https://doi.org/10.12691/education-2-8-16

Karadağ, E., \& Yücel, C. (2020). Yeni Tip Koronavirüs Pandemisi Döneminde Üniversitelerde Uzaktan Eğitim: Lisans Öğrencileri Kapsamında Bir Değerlendirme Çalışması. Yükseköğretim Dergisi, 10(2), 181-192. https://doi.org/10.2399/yod.20.730688

Karasar, N. (2017). Bilimsel Araştırma Yöntemi: Kavramlar Illkeler Teknikler (32th ed.). Ankara: Nobel Akademik Yayıncılı.

Karatepe, F., Küçükgençay, N., \& Peker, B. (2020). Öğretmen Adayları Senkron Uzaktan Eğitime Nasıl Bakıyor? Bir Anket Çalışması. Journal of Social and Humanities Sciences Research, 7(53), 1262-1274. https://doi.org/10.26450/jshsr. 1868

Kaur, G. (2020). Digital Life: Boon or Bane in Teaching Sector on COVID-19. CLIO An Annual Interdisciplinary Journal of History, 6(6), 416-427.

Kaymak-Demir, Z., \& Horzum, B., M. (2013). Çevrimiçi Öğrenme Öğrencilerinin Çevrimiçi Öğrenmeye Hazır Bulunuşluk Düzeyleri, Algıladıkları Yapı ve Etkileşim Arasındaki İlişki. Educational Sciences: Theory \& Practice, 13(3), 1783-1797. Retrieved from https://hdl.handle.net/20.500.12619/73217

Kırmız1, Ö. (2015). The Influence of Learner Readiness on Student Satisfaction and Academic Achievement in an Online Program at Higher Education. TOJET-Turkish Online Journal of Educational Technology, 14(1), 133-142.

Korkmaz, Ö., Çakır, R., \& Tan, S. S. (2015). Öğrencilerin E-Öğrenmeye Hazır Bulunuşluk ve Memnuniyet Düzeylerinin Akademik Başarıya Etkisi. Ahi Evran Üniversitesi Kırşehir Ĕgitim Fakültesi Dergisi, 16(3), 219-241.

Korucu, A. T., Usta, E., \& Çoklar, A. N. (2019). Eğitim Fakültesi Öğrencileri ile Turizm Fakültesi Öğrencilerinin Mobil Öğrenmeye Yönelik Tutumları. Kuramsal Ĕ̆itimbilim Dergisi, 12(1), 1-15. https://doi.org/10.30831/akukeg.512541

Kruger-Ross, M. J., \& Waters, R. D. (2013). Predicting Online Learning Success: Applying the Situational Theory of Publics to the Virtual Classroom. Computers \& Education, 61, 176-184. https://doi.org/10.1016/j.compedu.2012.09.015

Lorcu, F. (2015). Örneklerle Veri Analizi Spss Uygulamalı. Ankara: Detay Yayınc1lık.

Mavi, D., \& Erçăg, E. (2020). Analysis of the Attitudes and the Readiness of Maker Teachers Towards E-learning, with Use of Several Variables. International Online Journal of 
Education and Teaching, 7(2), 684-710.

Neupane, H. C., Sharma, K., \& Joshi, A. (2020). Readiness for the Online Classes during COVID-19 Pandemic Among Students of Chitwan Medical College. Journal of Nepal Health Research Council, 18(2), 316-319. https://doi.org/10.33314/jnhrc.v18i2.2725

Obi, I. E., Charles-Okoli, A. N., Agunwa, C. C., Omotowo, B. I., Ndu, A. C., \& Agwu-Umahi, O. R. (2018). E-learning Readiness from Perspectives of Medical Students: A Survey in Nigeria. Nigerian Journal of Clinical Practice, 21(3), 293-300. Retrieved from https://www.njcponline.com/text.asp?2018/21/3/293/226956

Ocak, G., \& Karakuş, G. (2014). Öğrencilerin Hazırbulunuşluk Düzeyleri ve İngilizce Dersine Yönelik Tutumları Arasındaki İlişkinin İncelenmesi. EKEV Akademi Dergisi, 18(58), 681-698.

Olcay, A., Döş, B., Sürme, M., \& Düzgün, M. (2018). Turizm Eğitimi Alan Öğrencilerin Elektronik Öğrenmeye Hazır Bulunuşluklarını Belirlemeye Yönelik Bir Çalışma. Kastamonu Ĕ̆itim Dergisi, 26(2), 427-438. https://doi.org/10.24106/kefdergi.389940

Oliver, R. (2001). Assuring the Quality of Online Learning in Australian Higher Education. In M. Wallace, A. Ellis, \& D. Newton (Eds.), Proceedings of Moving Online II Conference (pp. 222-231). Southern Cross University: Lismore, NSW. Retrieved from https://ro.ecu.edu.au/ ecuworks/4792

Ong, C. S., \& Lai, J. Y. (2006). Gender Differences in Perceptions and Relationships among Dominants of E-learning Acceptance. Computers in Human Behavior, 22(5), 816-829. https://doi.org/10.1016/j.chb.2004.03.006

Öztürk, D. S., Öztürk, F., \& Özen, R. (2018). The Relationship between Prospective Teachers' Readiness and Satisfactions about Web-Based Distance Education. Turkish Online Journal of Distance Education, 19(1), 147-162. https://doi.org/10.17718/tojde.382791

Peytcheva-Forsyth, R., Yovkova, B., \& Aleksieva, L. (2018). Factors Affecting Students' Attitudes towards Online Learning-The Case of Sofia University. Proceedings of the 44th International Conference on Applications of Mathematics in Engineering and Economics. https://doi.org/10.1063/1.5082043

Radha, R., Mahalakshmi, K., Kumar, V. S., \& Saravanakumar, A. R. (2020). E-learning during Lockdown of COVID-19 Pandemic: A Global Perspective. International Journal of Control and Automation, 13(4), 1088-1099.

Rhema, A., \& Miliszewska, I. (2014). Analysis of Student Attitudes towards E-learning: The Case of Engineering Students in Libya. Issues in Informing Science and Information Technology, 11, 169-190. https://doi.org/10.28945/1987

Rizun, M., \& Strzelecki, A. (2020). Students' Acceptance of the COVID-19 Impact on Shifting Higher Education to Distance Learning in Poland. International Journal of Environmental Research and Public Health, 17(18), 6468. https://doi.org/10.3390/ijerph171 86468 
Sakal, M. (2017). Çevrimiçi Öğrenmede Öğrencilerin Hazırbulunuşluk Düzeylerinin Demografik Özelliklerine Göre İncelenmesi. Sosyal ve Beşeri Bilimler Araştırmaları Dergisi, 18(39), 81-102.

Schwartz, S. H. (2012). An Overview of The Schwartz Theory of Basic Values. Online Readings in Psychology and Culture, 2(1). https://doi.org/10.9707/2307-0919.1116

Senemoğlu, N. (2018). Gelişim Öğrenme ve Öğretim Kuramdan Uygulamaya (26th ed.). Ankara: Anı Yayıncılık.

Smart, K. L., \& Cappel, J. J. (2006). Students' Perceptions of Online Learning: A Comparative Study. Journal of Information Technology Education, 5, 202-219. https://doi.org/10.2139/ ssrn. 3524610

So, T., \& Swatman, P. M. C. (2006). E-learning Readiness of Hong Kong Teachers. Hong Kong IT in Education Conference 2006 "Capacity Building for Learning through IT" (HKITEC2006), February 6-8, 2006, Hong Kong: Exhibition and Convention Centre. Retrieved from http://citeseerx.ist.psu.edu/viewdoc/download?doi=10.1.1.65.8121\&rep=rep1 \&type $=$ pdf

Suri, G., \& Sharma, S. (2013). Impact of Age on Student's Attitude towards E-learning: A Study on Panjab University, India. Gian Jyoti E-Journal, 3(2), 73-80.

Tedmem. (2020). COVID-19 Sürecinde Eğitim: Uzaktan Öğrenme, Sorunlar ve Çözüm Önerileri (Tedmem Analiz Dizisi 7). Ankara: Türk Eğitim Derneği Yayınları.

Tempelaar, D. T., Niculescu, A., Rienties, B., Gijselaers, W. H., \& Giesbers, B. (2012). How Achievement Emotions Impact Students' Decisions for Online Learning, and What Precedes Those Emotions. The Internet and Higher Education, 15(3), 161-169. https://doi.org/ 10.1016/j.iheduc.2011.10.003

Topal, A. D. (2016). Examination of University Students' Level of Satisfaction and Readiness for E-Courses and the Relationship between Them. European Journal of Contemporary Education, 15(1), 7-23. https://doi.org/10.13187/ejced.2016.15.7

Torun, E. D. (2020). Online Distance Learning in Higher Education: E-learning Readiness as A Predictor of Academic Achievement. Open Praxis, 12(2), 191-208. https://doi.org/10.5944/ openpraxis. 12.2.1092

Türkmen, B., Aşçı, Y., \& Zor, E. U. (2020). COVID-19 Sosyal İzolasyon Döneminde Meslek Yüksekokulu Öğrencilerinin E-Öğrenmeye Hazırbulunuşluk Düzeylerinin İncelenmesi: Çaycuma Meslek Yüksekokulu Örneği. Uluslararası Sosyal Araştırmalar Dergisi, 13(72), 691-700. https://doi.org/10.17719/jisr.10821

Uslusoy, B. (2017). Uzaktan Ĕ̆itime Yönelik Öğrenci Tutumları Üzerine Karşılaştırmalı Bir Çalışma: ABD/Türkiye Örneği (Master's Thesis, Beykent Üniversitesi, İstanbul).

Üstüner, M. (2006). Öğretmenlik Mesleğine Yönelik Tutum Ölçeğinin Geçerlik ve Güvenirlik Çalışması. Kuram ve Uygulamada Eğitim Yönetimi Dergisi, 12(1), 109-127. 
Warner, D., Christie, G., \& Choy, S. (1998). Readiness of VET Clients for Flexible Delivery Including On-Line Learning. Brisbane: Australian National Training Authority. Retrieved from http://hdl.voced.edu.au/10707/33256

Wei, H. C., \& Chou, C. (2020). Online Learning Performance and Satisfaction: Do Perceptions and Readiness Matter? Distance Education, 41(1), 48-69. https://doi.org/ 10.1080/01587919.2020.1724768

Y1lmaz, R. (2017). Exploring the Role of E-learning Readiness on Student Satisfaction and Motivation in Flipped Classroom. Computers in Human Behavior, 70, 251-260. https://doi.org/10.1016/j.chb.2016.12.085

Y1lmaz, R., Sezer, B., \& Yurdugül, H. (2019). Üniversite Öğrencilerinin E-Öğrenmeye Hazır Bulunuşluklarının İncelenmesi: Bartın Üniversitesi Örneği. Ege Eğitim Dergisi, 20(1), 180-195. https://doi.org/10.12984/egeefd.424614

Zaharah, Z., Kirilova, G. I., \& Windarti, A. (2020). Impact of Corona Virus Outbreak towards Teaching and Learning Activities in Indonesia. SALAM: Jurnal Sosial dan Budaya Syar-i, 7(3), 269-282. https://doi.org/10.15408/sjsbs.v7i3.15104

Zembylas, M. (2008). Adult Learners' Emotions in Online Learning. Distance Education, 29(1), 71-87. https://doi.org/10.1080/01587910802004852

Zhang, D. \& Nunamaker, J. (2003). Powering E-learning in The New Millennium: An Overview of E-learning and Enabling Technology. Information Systems Frontier, 5(2), 207-218. https://doi.org/10.1023/A:1022609809036

Zhu, C. (2012). Student Satisfaction, Performance, and Knowledge Construction in Online Collaborative Learning. Journal of Educational Technology \& Society, 15(1), 127-136.

\section{Copyright Disclaimer}

Copyright for this article is retained by the author(s), with first publication rights granted to the journal.

This is an open-access article distributed under the terms and conditions of the Creative Commons Attribution license (http://creativecommons.org/licenses/by/3.0/). 